\title{
Soluble tumour necrosis factor receptors p55 and p75 in the urine monitor disease activity and the efficacy of treatment of inflammatory bowel disease
}

\author{
F Hadziselimovic, L R Emmons, H Gallati
}

University Clinics, Department of Gastroenterology, Children's Hospital, Basle, Switzerland F Hadziselimovic L R Emmons

F Hoffmann-La Roche Ltd, Pharmaceutical Research - New Technologies, Basle, Switzerland

H Gallati

Correspondence to: Professor F Hadziselimovic, Basler Children's Hospital, Römergasse 8, CH-4005 Römergasse 8, CH Basle, Switzerland. 21 November 1994

\begin{abstract}
The aim of the study was to discover if soluble tumour necrosis factor receptors (sTNF-R p55 and p75) in the urine of patients with inflammatory bowel disease (IBD) could be used to monitor the different stages of the activity of the diseases. Twenty five patients with either Crohn's disease or ulcerative colitis were followed up during a longterm study. The 16 patients who become acutely ill with either Crohn's disease or ulcerative colitis had significantly higher concentrations of sTNF-R p55 and p75 in their urine compared with those who were in remission, or those who were normal controls. There was a significant correlation between increased concentrations $(>20 \mathrm{ng} / \mathrm{ml})$ of both sTNF-R p55 and p75 in the urine and a high Crohn's disease activity index (CDAI) and colitis activity index (CAI). Therefore, determination of sTNF-R is a good non-invasive parameter that can be used to assess the activity of disease and the efficacy of treatment.
\end{abstract}

(Gut 1995; 37: 260-263)

Keywords: tumour necrosis factor, inflammatory bowel disease, urine.
Tumour necrosis factor $\alpha$ (TNF $\alpha$ ) is a proinflammatory cytokine that is released by activated macrophages and lymphocytes. It is an important immunological mediator in response to injury, infection, and neoplasia. ${ }^{12}$ Its beneficial role is that of a modulator of metabolic activities in different tissues. ${ }^{3-7}$ Recently, increased concentrations of it have been detected in the serum of patients with inflammatory bowel disease (IBD) ${ }^{8}$ while others have implicated mononuclear cells of the lamina propria of patients with IBD responsible for enhanced secretion of the cytokine. ${ }^{9}{ }^{10}$ Hudson et al assessed the concentrations of the two types of soluble TNF receptors (sTNF-R), p55, and p75, in the serum in patients with Crohn's disease. ${ }^{8}$ Those patients with an active disease had higher concentrations of the sTNF-Rs in their serum compared with the normal controls and those in a quiescent state of the disease. We have for the first time correlated the activity of IBD, both ulcerative colitis and Crohn's disease, in children with the concentrations of the sTNF$\mathrm{R}$ p55 and p75 in their urine and serum.

\section{Methods}

Subjects

Twenty five children with IBD, Crohn's disease or ulcerative colitis, have been followed up in a longterm study. The 92 determinations of the concentration of sTNF-R p55 and p75, were assessed in the urine either while the patients were in remission for at least three months, or during the acute stage of the diseases. The concentration of the sTNF-Rs was compared with 17 normal controls of comparable age. The activity of the disease was estimated for Crohn's disease according to Crohn's disease activity index (CDAI)-Best index, ${ }^{11}$ and for ulcerative colitis according to colitis activity index (CAI) developed by Rachmilewitz. ${ }^{12}$ All of the patients had a longstanding IBD, confirmed histologically and radiologically. The exacerbation of the disease was estimated clinically by evaluating the CDAI or CAI, by an endoscopic procedure, and a histological examination of the biopsy specimens. During an acute relapse, other laboratory criteria were also assessed: $\mathrm{C}$ reactive protein, albumin, complete blood count, and urine. The relapse of Crohn's disease was characterised when the CDAI was $>200$, and confirmed histologically and endoscopically; a
Figure 1: A comparison of the quantity of sTNF-Rs p55 in the pooled urine of 20 normal subjects during $a 36$ hour period of time. Soluble TNF-R p55 and p 75 were analysed at regular intervals. There was no significant difference among the samples analysed. As $s T N F-R$ p 55 correlated significantly with sTNF-R p 75 (Fig 5), only data for $s T N F-R$ p55 have been presented. 

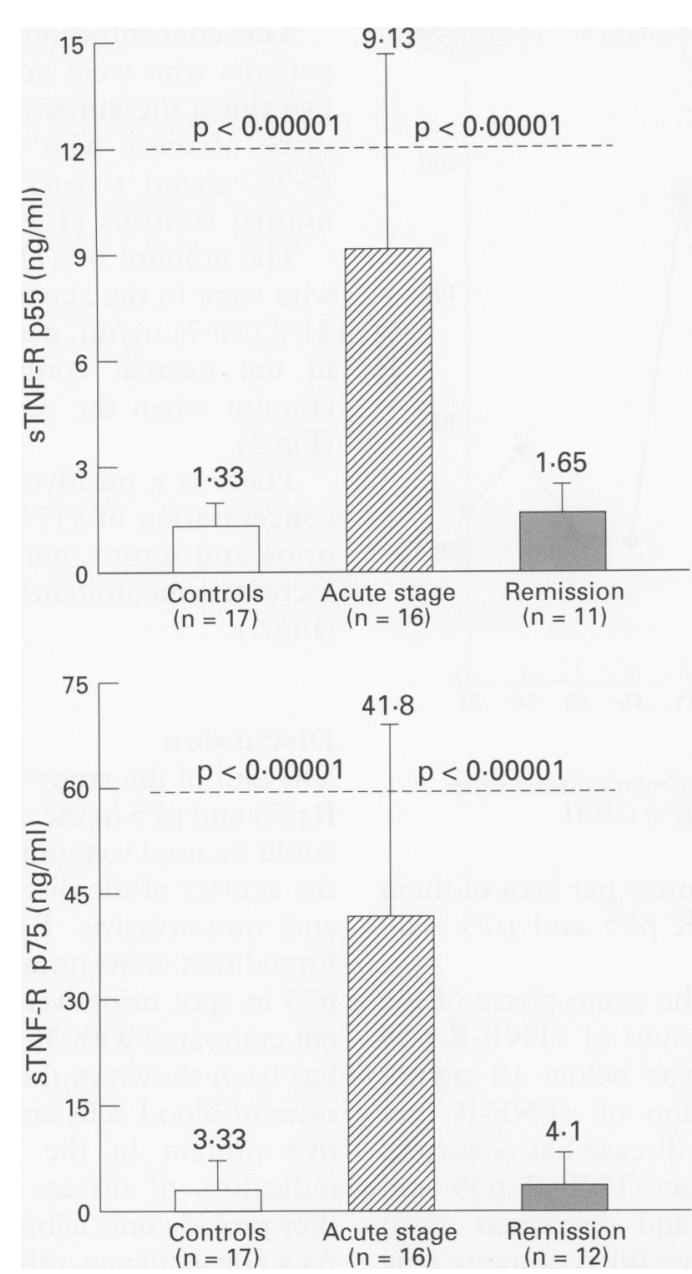

Figure 2: The concentration of $s T N F-R$ p55 and $p 75$ during active and inactive state of IBD compared with normal controls of comparable age.

CAI $>6$ indicated a relapse of ulcerative colitis; it also was confirmed histologically and endoscopically. Patients were considered to be in remission when their CDAI was $<150$ and CAI was $<4$.

Determination of $s T N F-R p 55$ and $p 75$

The concentration of sTNF-R p55 and p75 was determined using an enzyme linked

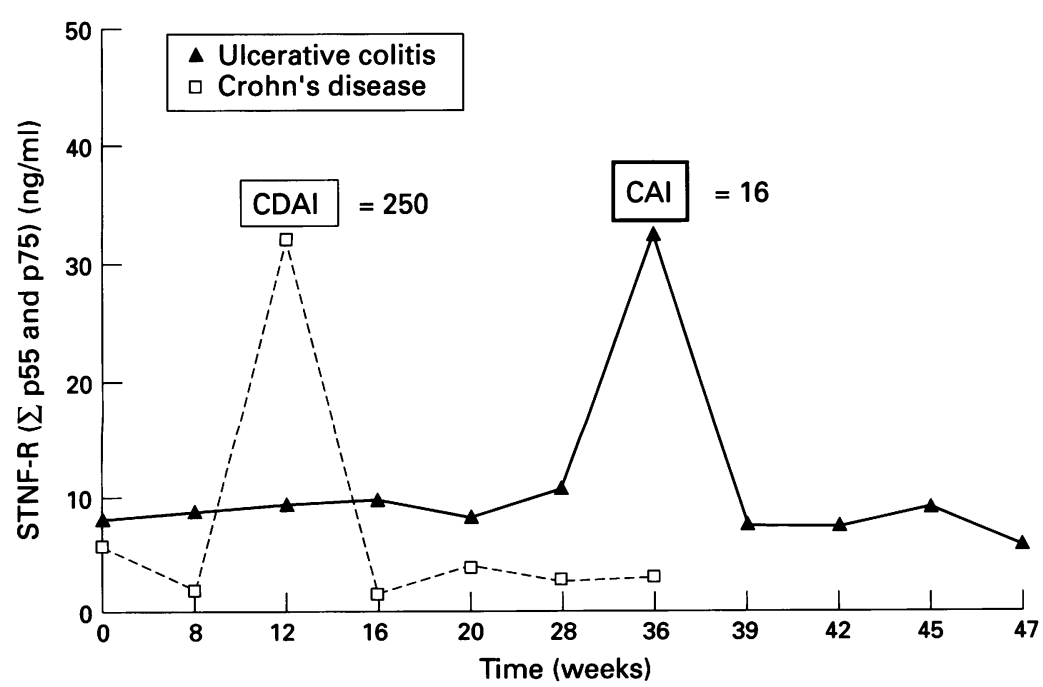

Figure 3: Longitudinal follow up of sTNF-Rs in two patients with Crohn's disease and ulcerative colitis. immunological and biological binding assay (ELIBA); monoclonal antibodies raised against the human sTNF-R p55 and p75 coat the walls of microtitre plates. Enzyme linked binding assays with a TNF $\alpha$ horseradish peroxidase conjugate as detecting agent were applied for qualitative and quantitative determinations of the soluble TNF receptors. Both tests were highly specific for TNF $\alpha$ receptor type I (p55) and type II (p75), respectively; there was no cross reactivity between the two receptors. The TNF $\alpha$ enzyme conjugate was present in surplus and the addition of up to 40 $\mathrm{ng} / \mathrm{ml}$ of recombinant TNF $\alpha$ had no influence on the assays. Reproducibility of both tests was $3-10 \%$. Microtitre plates were coated with either the monoclonal mouse antihuman TNF receptor antibody (clone htr-20) directed against type I (p55) or mouse antihuman TNF receptor antibody (clone utr-4) against type II (p75) receptors. In a single step reaction, the plasma or urine was incubated with peroxidase bound TNF in the wells of microtitre plates. After an incubation period of 24 hours, unbound material was removed by a washing step and the amount of bound peroxidase was determined by a short incubation with tetramethylbenzidine. On stopping the reaction with sulphuric acid, the colour changed to yellow, and its intensity was determined at $450 \mathrm{~nm}$ by a computerised multichannel photometer (Flow, Meckenheim FRG). The amount of human TNF receptor was calculated from the standard curve prepared with recombinant TNF $\alpha$ receptor. This assay has a range of $100-5000 \mathrm{pg} / \mathrm{ml}$ of TNF receptor.

\section{Urine analysis}

Earlier analyses of sTNF-Rs p55 and p75 in the urine of 20 normal subjects, sampled at regular intervals for 36 hours (Fig 1), showed no significant difference among the samples. Therefore, spot urine analyses were used exclusively in the study.

\section{Statistical analysis}

All data are expressed as mean (SD). Data were analysed using the Mann-Whitney $U$ test and Fisher test. A probability of less than $0.05 \%$ was considered to be significant.

\section{Results}

The status of the disease in patients with IBD is reflected in the amounts of sTNF-R p55 and p75 present in the urine. Eighty one per cent of patients (13 of 16) during an acute episode of IBD (CAI > 200; or, CAI >6) had sTNF-R p55 and p75 $>20 \mathrm{ng} / \mathrm{ml}$. Three patients during the acute stage of IBD had sTNF-R p55 and p75 $<20 \mathrm{ng} / \mathrm{ml}$ but $>15 \mathrm{ng} / \mathrm{ml}$. Notably, not a single patient had sTNF-R p55 and p75 $<10$ $\mathrm{ng} / \mathrm{ml}$ during the acute stage of IBD (Fig 2). The inflammatory symptoms were caused by infectious episodes and not by fibrotic strictures. The concentration of the receptors was significantly higher compared with those who were in remission: CDAI $<150$; or, CAI $<4$ 


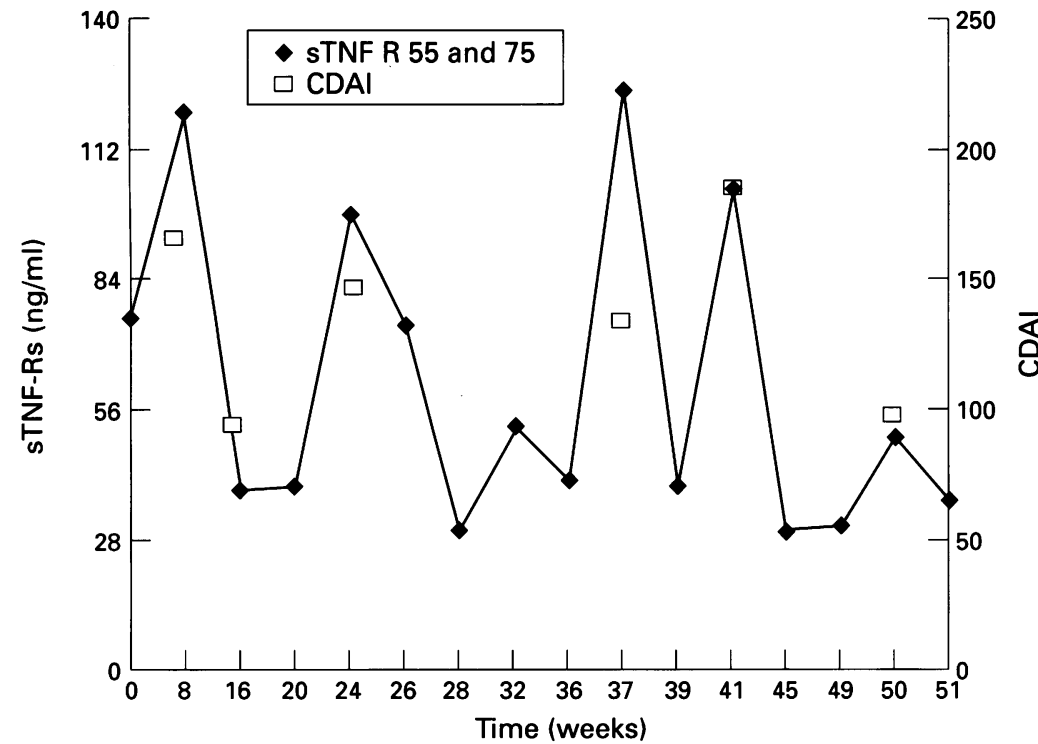

Figure 4: Longitudinal follow up of sTNF-Rs in a patient with Crohn's disease never entering into complete remission but comparatively well according to CDAI.

(Fisher test: $<0 \cdot 001)$. Ninety per cent of them $(69$ of 77$)$ had sTNF-R p55 and p75 $<20$ $\mathrm{ng} / \mathrm{ml}$.

For example, during the acute phase of the ulcerative colitis, the amount of sTNF-R p55 and p75 in the urine was below $10 \mathrm{ng} / \mathrm{ml}$, ostensibly, a concentration of STNF-R that shows a remission of the disease has occurred. The concentration of the sTNF-R p55 and p75 rose to $33 \mathrm{ng} / \mathrm{ml}$ and decreased again significantly during successful treatment (Fig 3). Similar findings were seen in a patient with Crohn's disease: during the acute stage of the disease, the concentration of the sTNF-R p55 and p75 rose to $31 \mathrm{ng} / \mathrm{ml}$ in the urine and dropped precipitously during the course of treatment to less than $8 \mathrm{ng} / \mathrm{ml}$ in the urine (Fig 3).

Another patient with persistent activity of Crohn's disease has had the concentration of sTNF-Rs monitored closely for over a year (Fig 4). During that period of time, his disease has remained in a comparatively quiescent state (according to the CDAI index: between 96 and 190). He has never achieved total remission, however, during that time; the concentration of sTNF-Rs has remained above $30 \mathrm{ng} / \mathrm{ml}$, three times higher than the concentration of sTNFRs seen in the two patients (Fig 3) when they achieved remission of their disease.

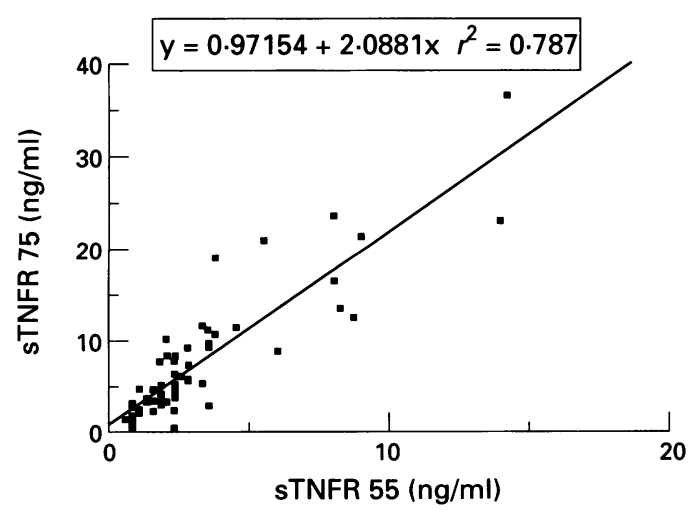

Figure 5: Correlation between the concentrations of $s T N F-R$ p55 and p75 in the urine of patients with IBD.
The concentrations of sTNF-R p55 in 16 patients who were acutely ill were more than five times the amount that was present in the urine of those who were in remission $(9.13$ $(5.72) \mathrm{ng} / \mathrm{ml} v 1.65(0.89) \mathrm{ng} / \mathrm{ml})$, or were normal controls $(1.33(0.83) \mathrm{ng} / \mathrm{ml})$ (Fig 2).

The amount of sTNF-R p75 in 16 patients who were in the acute stage of the disease was $41.8(30 \cdot 7) \mathrm{ng} / \mathrm{ml}$, nearly 13 times the amount in the normal controls and 10 times the amount when the patients were in remission (Fig 2).

There is a positive correlation between the concentration of sTNF-R p55 and p75 in the urine and serum; both sTNF-R p55 and p75 increase concomitantly and correlate positively (Fig 5).

\section{Discussion}

The aim of the study was to discover if sTNF$\mathrm{R} p 55$ and $\mathrm{p} 75$ in the urine of patients with IBD could be used to monitor the different stages of the activity of the diseases. The assay is simple and non-invasive. Earlier studies have confirmed that concentrations of STNF-R p 55 and p75 in spot urine were not significantly different compared with 36 hour samples of urine. It has been shown in the past that sedimentation rates of blood cells and the amount of $\mathrm{C}$ reactive protein in the serum are not reliable indicators of disease activity. ${ }^{1112}$ Therefore, they provide only a limited view of the problem. As a consequence, other indices such as CDAI and CAI have evolved as indicators of disease activity in IBD. ${ }^{13} 14$ The concentrations of sTNF-R can be assessed in either the urine or serum. Of course, the less invasive and most expedient procedure is to measure the amount of STNF-R in the urine. Both assessments provided data that lead to the same conclusion: the amount of sTNF-R in the urine is an excellent method of assessing the activity of the disease and a simple and accurate method of assessing the efficacy of treatment.

An important caveat must be emphasised, however: in that the TNF $\alpha$ is a pro-inflammatory cytokine that is released by activated macrophages and lymphocytes, its presence may not be associated with the particular inflammatory response that is being closely monitored. For that reason, other concomitant infections of inflammations must be correctly diagnosed; increased concentrations of TNF $\alpha$ and its receptors are ubiquitous indications of a serious inflammatory response occurring within the body.

In conclusion, the assay is simple and noninvasive; it reflects the degree of activity of a disease and the efficacy of treatment of IBD.

1 Beutler B, Cerami A. Tumor necrosis, cachexia, shock, and inflammation: a common mediator. Ann Rev Biochem 1988; 57: 505-18.

2 Beutler B, Cerami A. The biology of cachectin/TNF - a primary mediator of the host response. Ann Rev Immunol 1989; 7: 625-55.

3 Tracy KJ, Cerami A. Metabolic responses to cachectin/TNF: a brief review. Ann NY Acad Sci 1990; 587: 325-31.

4 Tracy KJ, Wei H, Manogue KR, Fong Y, Hesse DG, Lowry SF. Cachectin/tumor necrosis factor induces cachexia anemia and inflammation. $\mathcal{f} \operatorname{Exp}$ Med 1988; 167: 1211-27. 
5 Fong Y, Maldawer LL, Marano MA, Wei H, Barber A, Manogue KR, et al. Chronic cachectin/TNF or IL-1 alpha induces cachexia with redistribution of body proteins. $\mathrm{Am}$ f Physiol 1989; 256: R659-65.

6 Johnson RA, Wadelow TA, Caro J, Oliff A, Roodman GD. Chronic exposure to tumor necrosis factor in vivo preferChronic exposure to tumor necrosis factor in vivo prefer-
entially inhibits erythropoiesis in nude mice. Blood 1989; 74: $130-8$.

7 Tracy KJ, Morgello S, Koplin B, Fahley TJ III, Fox J, Alco $\mathrm{A}$, et al. Metabolic effects of cachectin/tumor necrosis factor are modified by site of production. $\mathcal{f}$ Clin Invest 1990; 86: 2014-24.

8 Hudson M, Gallati H, Ryff JC, Pounder RE, Wakefield AJ. Serum tumour necrosis factor (TNF) and soluble TNF receptors p55 and p75 in Crohn's disease. Gastroenterology 1993; 104 (suppl): A715.

9 Reinecker H-C, Steffen M, Witthoeft T, Pflueger I, Schreiber S, MacDermott RP, et al. Enhanced Schreiber S, MacDermott RP, et al. Enhanced
secretion of tumour necrosis factor-alpha, IL-6, and IL- $1 \beta$ by isolated lamina propria mononuclear cells from patients with ulcerative colitis and Crohn's disease. Clin Exp Immunol 1993; 94: 174-81.

10 Murch AH, Braegger CP, Walker-Smith JA, MacDonald TT. Location of tumour necrosis factor alpha by immunohistochemistry in chronic inflammatory bowel disease. Gut 1993; 34: 1705-9.

11 Best WR, Becktel JM, Singleton JW, Kern F. Development of a Crohn's disease activity index. Gastroenterology 1976; 70: 439-44.

2 Rachmilewitz D. Coated mesosalazine versus sulphasalazine in the treatment of active ulcerative colitis: a randomized trial. BMF 1989; 298: 82-6.

13 André C, Descos L, André F, Vignal J, Landais P, Fermanian $\mathrm{J}$. Biological measurements of Crohn's disease activity - a reassessment. Hepatogastroenterology 1985; 32: 135-7.

14 Maratka Z. Crohn's disease activity indices: need for distinguishing activity from severity. Hepatogastroenterology guishing activity 